\title{
Herbal Medicine Must Be Treated with Care-A Case Report on Aconitine
}

\author{
Nadine Theofel *, Marlene Wagner, Elke Vejmelka, Stefan Scholtis and Michael Tsokos \\ Governmental Institute of Legal Medicine and Forensic Sciences, Turmstraße 21, D-10559 Berlin, Germany; \\ marlene.wagner@germed.berlin.de (M.W.); elke.vejmelka@germed.berlin.de (E.V.); \\ stefan.scholtis@germed.berlin.de (S.S.); michael.tsokos@germed.berlin.de (M.T.) \\ * Correspondence: nadine.theofel@germed.berlin.de; Tel.: +49-30-901728-188
}

Academic Editor: Francesco Sessa

Received: 29 March 2021; Accepted: 3 May 2021; Published: 5 May 2021

\begin{abstract}
Pathologists usually only request a screening for natural toxic substances if plant material has been observed during autopsy or if there exists a hint in the police investigation file. This situation is aggravated by the fact that most toxins are not covered by typical immunoassays and gas chromatography-mass spectrometry (GC-MS) profiling systems. In addition, only a few forensic toxicological libraries based on liquid chromatography coupled to high-resolution tandem mass spectrometry (LC-HRMS/MS) exist. In the following case, femoral blood and urine were applied to systematic toxicological analysis (STA). However, the concentrations determined in blood did not lead to death. Consequently, a liquid chromatography high-resolution tandem mass spectrometry (LC-HRMS/MS) screening approach was applied. Aconitine was quantitated in all specimens taken during autopsy and urine and bile fluid screened for aconitine metabolites. Aconitine, jesaconitine, hypaconitine, and mesaconitine were found in the root piece collected from the duodenum. Apart from aconitine, no other alkaloids were detected in the urine or in the femoral blood sample. The highest concentrations of aconitine were found in gastric content $(55.2 \mu \mathrm{g} / \mathrm{mL})$, bile fluid $(11.7 \mu \mathrm{g} / \mathrm{mL})$, and liver $(9.14 \mu \mathrm{g} / \mathrm{g})$, and least in femoral blood $(0.15 \mu \mathrm{g} / \mathrm{mL})$ and cerebrospinal fluid $(0.07 \mu \mathrm{g} / \mathrm{mL})$. The liver/peripheral blood ratio amounted to $61 \mathrm{~L} / \mathrm{kg}$ and indicated that aconitine undergoes postmortem redistribution. During our metabolism investigation, we found 3-dehydrogen-aconitine in the urine and bile fluid sample and $\mathrm{N}$-deethyl-aconitine only in the bile fluid sample. If the routine GC-MS screening approach does not come up with a toxin, then LC-HRMS/MS profiling could represent the method of choice. In this case aconitine was identified. The concentrations determined were compared to those reported in literature and clearly indicate that the deceased died due to an aconitine overdose.
\end{abstract}

Keywords: plant; toxin; aconitum; aconite; monkshood; wolfsbane; concentration; LC-MS/MS; STA; screening

\section{Introduction}

Aconitum plants belong to the Ranunculaceae family and are frequently employed as herbal medicine in Asian countries [1,2]. As the tuber is well-known for its pharmaceutical properties due to its anti-inflammatory, analgesic, and cardiotonic effects [3], it has been used as a homicidal and suicidal agent in the past [4]. The tuber contains the toxic diesterditerpene-type aconitum alkaloids aconitine $\left(\mathrm{C}_{34} \mathrm{H}_{47} \mathrm{NO}_{11}\right)$, mesaconitine $\left(\mathrm{C}_{33} \mathrm{H}_{45} \mathrm{NO}_{11}\right)$, hypaconitine $\left(\mathrm{C}_{33} \mathrm{H}_{45} \mathrm{NO}_{10}\right)$, and jesaconitine $\left(\mathrm{C}_{35} \mathrm{H}_{49} \mathrm{NO}_{12}\right)[5,6]$. However, the composition of the terpenoid alkaloids depends on species, place of origin, time of harvest, and method of processing [7]. These alkaloids can cause conduction blocking and paralysis through action on the sodium channel in the axons [8]. The neurotoxin aconitine produces prolonged depolarization and thus prevents repolarization of the excitable membrane [9]. 
As a consequence, a combination of local (tingling and numbness in mouth and tongue), systemic sensory (in the extremities), and motor (weakness in the extremities) symptoms is expected [8]. Even a low dose (1-2 $\mathrm{mg}$ ) is sufficient to cause an intoxication. The elimination half-life is 3-18 $\mathrm{h}$ [8].

First symptoms occur within the first hour after ingestion [10] as this compound is rapidly absorbed by the upper gastrointestinal tract. They include paresthesia, sweating, and nausea. These symptoms are followed by severe vomiting, colicky diarrhea, intense pain, paralysis of the skeletal muscles, and life-threatening arrhythmia. Finally, death occurs as a result of respiratory paralysis and cardiac arrest $[4,11]$.

This report presents a screening method for the analysis of naturally occurring toxic substances in urine. As proof of concept, a fatal aconitine poisoning is presented, in which concentrations in biological fluids, tissues, and gastrointestinal content are summarized. The values determined exceed those reported in literature. The high concentration of aconitine determined might be explained by the fact that the root material was soaked in ethanol. We assume that the deceased had drunk the aconite tincture and eaten some of the root pieces, respectively.

\section{Materials and Methods}

\subsection{Case History}

A 19-year-old man (height $168 \mathrm{~cm}$, weight $62 \mathrm{~kg}$, BMI $21.97 \mathrm{~kg} / \mathrm{m}^{2}$ ) was found dead at home by his parents. He was lying in bed in supine position and his eyes were widely opened. High-proof alcoholic beverages, several medications (ibuprofen and Vomex A), material resembling controlled substances, and a bowl filled with root pieces with a star-shaped cross section (Figure 1) were secured. In addition, vomit including root pieces was located in the area surrounding him.

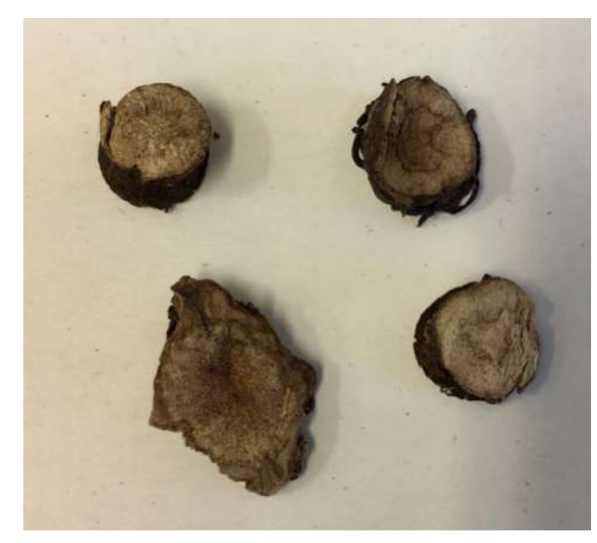

(a)

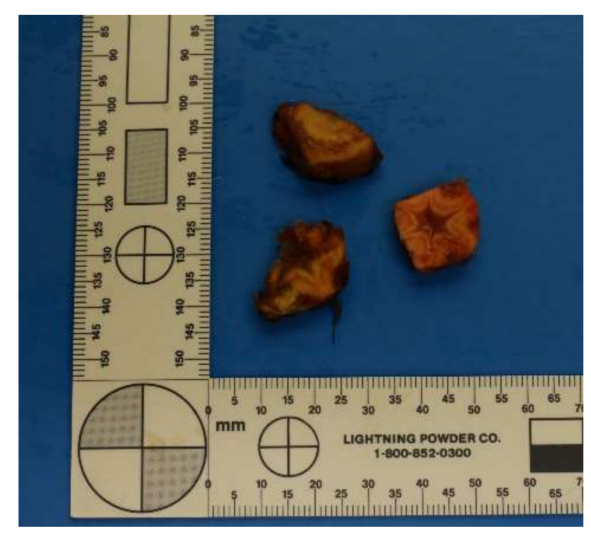

(b)

Figure 1. Root pieces collected from (a) the bowl and (b) the duodenum.

During autopsy $1630 \mathrm{~g}$ brain, $330 \mathrm{~g}$ heart, $1515 \mathrm{~g}$ liver, $40 \mathrm{~mL}$ gastric content, $625 \mathrm{~g}$ left lung, $680 \mathrm{~g}$ right lung, $250 \mathrm{~g}$ spleen, $125 \mathrm{~g}$ right kidney, $125 \mathrm{~g}$ left kidney, and $440 \mathrm{~mL}$ urine were obtained. Thereof, $24 \mathrm{~g}$ femoral blood, $26 \mathrm{~g}$ urine, $40 \mathrm{~g}$ gastric contents, $11 \mathrm{~g}$ bile fluid, $60 \mathrm{~g}$ heart blood, $80 \mathrm{~g}$ liver, and $11 \mathrm{~g}$ cerebrospinal fluid were available for toxicological analysis. The deceased person did not have any chronic disease related to liver, kidney, or heart. Only a minimal heart enlargement was determined. However, three yellow-brown colored pieces looking like the root pieces from the bowl were found in the duodenum (Figure 1). Signs of central death, such as blood-filled inner organs, pulmonary edema, cerebral swelling, a frothy secretion in the airways, and a filled urinary bladder were observed. From the root pieces in the duodenum, the widely opened eyes, the blood-filled inner organs, and the situation in which the body was found, we assumed an intoxication. 


\subsection{Systematic Toxicological Analysis (STA)}

Ethanol was determined with a Clarus 580 gas chromatograph-flame ionization (GC-FID) system from Perkin Elmer (Shelton, CT, USA). The presence of barbiturates, benzodiazepines, opiates, cocaine, cannabinoids, methadone, amphetamine, and salicylate was checked with the help of cloned enzyme donor immunoassay $\left(\mathrm{CEDIA}^{\mathrm{TM}}\right.$ ) Drugs of Abuse Assays using the Indiko instrument from Thermo Fisher Scientific (Waltham, MA, USA). The downstream systematic toxicological analysis was conducted with a Finnigan Trace GC 2000 system equipped with a programmed temperature vaporization (PTV) injector (Thermo Quest, Manchester, UK). The capillary column used was a Zebron ZB-5MSi (Phenomenex, Torrance, CA, USA) and exhibited the following quality parameters: $30 \mathrm{~m} \times 0.25 \mathrm{~mm} \times 0.25 \mu \mathrm{m}$. Medications were quantitated with an Agilent Technologies 1290 Infinity high-performance liquid chromatography system coupled to a diode array detector (HPLC-DAD) (Agilent, Waldbronn).

\subsection{Quantitation of Aconitine}

One hundred microliters $(100 \mu \mathrm{L})$ urine, $20 \mu \mathrm{L}$ gastric content, $20 \mu \mathrm{L}$ bile fluid, and $200 \mu \mathrm{L}$ cerebrospinal fluid were spiked with internal standard $\left(10 \mu \mathrm{L}\right.$ nortriptyline- $\left.\mathrm{d}_{3}, 1 \mathrm{ng} / \mu \mathrm{L}\right)$ and filled up to $1 \mathrm{~mL}$ with $4 \mathrm{mM}$ ammonium formate buffer. A $200 \mu \mathrm{L}$ blood sample was mixed with internal standard $(10 \mu \mathrm{L}$ nortriptyline- $\mathrm{d} 3,1 \mathrm{ng} / \mu \mathrm{L})$, the existing protein precipitated with $590 \mu \mathrm{L}$ methanol, $400 \mu \mathrm{L}$ of the upper phase transferred to a glass vial, and acidified with $10 \mu \mathrm{L}$ 2-propanol/hydrochloric acid prior to evaporation. The resulting residue was reconstituted in $20 \mu \mathrm{L}$ methanol and $480 \mu \mathrm{L}$ buffer. A $1 \mathrm{~g}$ liver sample was spiked with internal standard, soaked in $10 \mathrm{~mL}$ ammonium formate buffer, mashed using a retch mill, and $100 \mu \mathrm{L}$ supernatant-diluted with $900 \mu \mathrm{L}$ buffer.

All samples were injected into a HPLC-MS/MS system (HPLC: Prominence liquid chromatograph, Shimadzu, Duisburg, Germany; MS/MS: 4000 QTRAP ${ }^{\circledR}$, Sciex, Darmstadt, Germany). Separations were performed on a Phenomenex Kinetex C18 column $(100 \times 3 \mathrm{~mm}$, particle size $2.6 \mu \mathrm{m})$ equipped with a C18 $4 \times 2.0 \mathrm{~mm}$ security guard ${ }^{\mathrm{TM}}$ cartridge (Phenomenex, Aschaffenburg, Germany). Liquid chromatography (LC) conditions were as follows: column $25^{\circ} \mathrm{C}$, solvent A: water supplemented with $4 \mathrm{mM}$ ammonium formate, solvent B: methanol supplemented with $4 \mathrm{mM}$ ammonium formate, mobile-phase gradient: solvent B held for $1 \mathrm{~min}$ at $5 \%$, increase to $100 \%$ within $15 \mathrm{~min}$, held at $100 \%$ for $10 \mathrm{~min}$, spaced back to $5 \%$ within $4 \mathrm{~min}$, and held at $5 \%$ for $10 \mathrm{~min}$, total flow rate $0.4 \mathrm{~mL} / \mathrm{min}$, injection volume $20 \mu \mathrm{L}$. Tandem mass spectrometry (MS/MS) transitions for aconitine were as follows; quantifier transition: 646 -> 586 (declustering potential: 106 volts; collision energy: 47 volts; collision cell exit potential: 18 volts), qualifier transition: 646 -> 105 (declustering potential: 106 volts; collision energy: 105 volts; collision cell exit potential: 6 volts) and those for the internal standard Nortriptylin- $\mathrm{d}_{3}$ as follows: 267 -> 233 (declustering potential: 76 volts; collision energy: 21 volts; collision cell exit potential: 10 volts).

\subsection{Screening Urine and Blood for Naturally Occurring Toxic Substances}

Qualitative LC-HRMS/MS analysis was conducted on a Nexera XR LC system (Shimadzu, Duisburg, Germany) coupled to a Sciex X500R QTOFMS instrument (Sciex, Darmstadt, Germany). The LC conditions were equal to those described for the HPLC-4000 QTRAP ${ }^{\circledR}$ system. The general mass spectrometry settings were as follows: $\mathrm{SWATH}^{\circledR}$, polarity positive, ion source gas 1: $40 \mathrm{psi}$; ion source gas 2: $60 \mathrm{psi}$; curtain gas: $35 \mathrm{psi}$; CAD gas: $7 \mathrm{psi}$; temperature: $600^{\circ} \mathrm{C}$, spray voltage 5500 volts, and those for the MS as follows: $\mathrm{m} / \mathrm{z}$ 105-1000; accumulation time: $200 \mathrm{~ms}$; declustering potential 60 volts; collision energy 10 volts, and those for the MS/MS as follows: $m / z$ 50-1000; accumulation time: $70 \mathrm{~ms}$; charge state 1 ; declustering potential 60 volts; collision energy 35 volts; collision energy spread 15 volts, with 36 windows overlapping by $1 \mathrm{Da}$. 


\section{Results}

\subsection{Systematic Toxicological Analysis Does Not Come Up with a Toxin}

Ethanol, ibuprofen, diphenhydramine, trimethoprim, and 8-chlortheophylline were found in the urine sample. Finally, $1.1 \%$ ethanol, $3.5 \mu \mathrm{g} / \mathrm{mL}$ ibuprofen, $0.1 \mu \mathrm{g} / \mathrm{mL}$ diphenhydramine, $1.8 \mu \mathrm{g} / \mathrm{mL}$ trimethoprim, and $1 \mu \mathrm{g} / \mathrm{mL}$ 8-chlortheophylline were quantitated in femoral blood. As these concentrations can be settled within the therapeutic range, the urine sample was profiled by LC-HRMS/MS. For this purpose, a dedicated method for the analysis of natural toxic substances was compiled (Table 1).

Table 1. Analytical data of toxic natural compounds. These include retention time (RT), high-resolution mass of the protonated molecular ion or the potassium adduct, and characteristic MS/MS fragments of the $[\mathrm{M}+\mathrm{H}]^{+}$or $[\mathrm{M}+\mathrm{K}]^{+}$adduct after collision-induced dissociation. For this purpose, $2 \mathrm{mg}$ of each compound were weighed, dissolved in $20 \mathrm{~mL}$ methanol, and diluted to $0.1 \mu \mathrm{g} / \mathrm{mL}$ with $4 \mathrm{mM}$ ammonium formate.

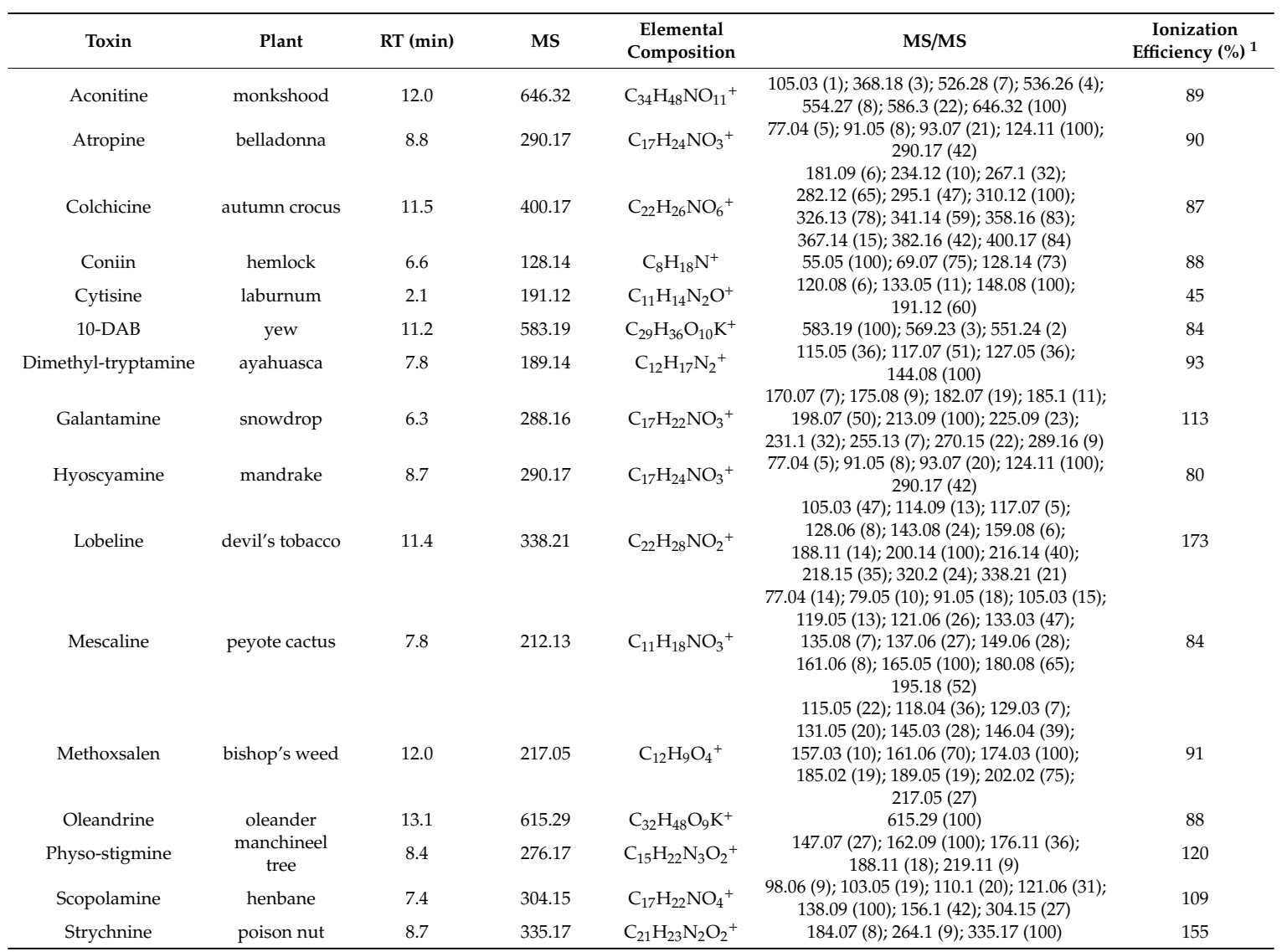

${ }^{1}$ For the estimation of the ionization efficiency, five arbitrarily chosen urine samples were spiked with $0.1 \mu \mathrm{g} / \mathrm{mL}$ toxin. Then, the ratio between the spiked and standard sample was estimated and averaged across all urine samples investigated.

This method is not restricted to the substances listed. It can be applied to any substance exhibiting a molecular weight within the set mass range and a concentration in the low $\mu \mathrm{g} / \mathrm{mL}$ range.

\subsection{Aconitine Might Be the Toxin}

Besides ibuprofen, diphenhydramine, trimethoprim, and 8-chlortheophylline, the alkaloid aconitine was detected (Figure 2). The MS1 spectrum of aconitine only exhibited a protonated molecular ion at $m / z$ 646.32, corresponding to $\mathrm{C}_{34} \mathrm{H}_{48} \mathrm{NO}_{11}{ }^{+}(-2.8 \mathrm{ppm})$. No $[\mathrm{M}+\mathrm{K}]^{+},[\mathrm{M}+\mathrm{Na}]^{+}$, or $\left[\mathrm{M}+\mathrm{NH}_{4}\right]^{+}$adduct was detected. In the MS/MS spectrum, one major fragment at $\mathrm{m} / \mathrm{z} 586.30$ 
$\left(\mathrm{C}_{32} \mathrm{H}_{44} \mathrm{NO}_{9}{ }^{+} ; 1.7 \mathrm{ppm}\right)$, resulting from the loss of acetic acid, was observed. In addition, minor fragments at $m / z 554.28\left(\mathrm{C}_{31} \mathrm{H}_{40} \mathrm{NO}_{8}{ }^{+} ; 1.6 \mathrm{ppm}\right), \mathrm{m} / z 526.28\left(\mathrm{C}_{30} \mathrm{H}_{40} \mathrm{NO}_{7}{ }^{+} ; 1.2 \mathrm{ppm}\right)$, and $\mathrm{m} / z 368.19$ $\left(\mathrm{C}_{22} \mathrm{H}_{26} \mathrm{NO}_{4}{ }^{+} ;-0.6 \mathrm{ppm}\right)$ were detected. This fragmentation pattern is in accordance with the one published in literature [12].

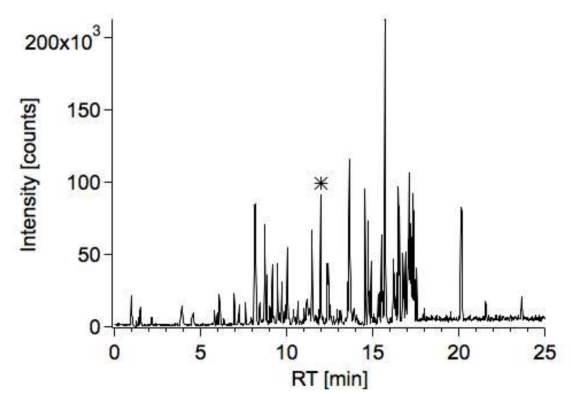

(a)

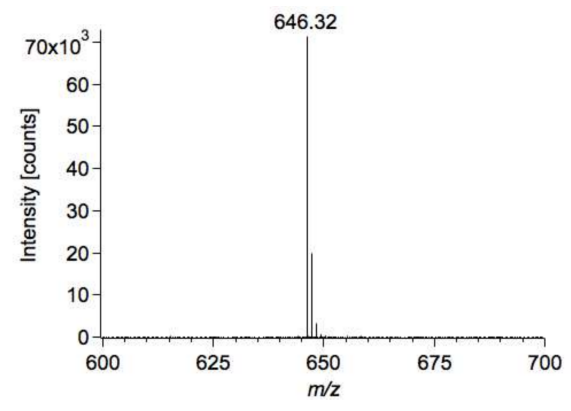

(c)

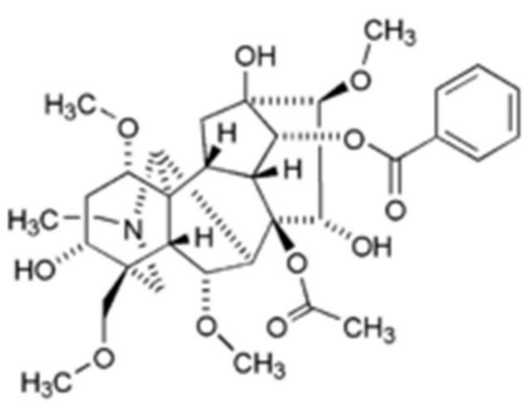

(b)

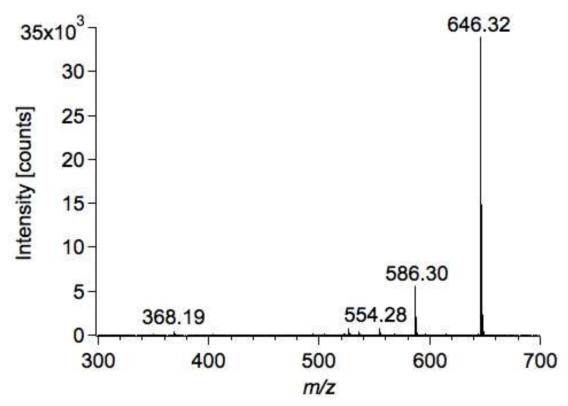

(d)

Figure 2. LC-MS chromatogram of the urine sample: (a) base peak chromatogram; (b) chemical structure; (c) mass spectrum of the peak marked with an asterisk resulting from aconitine; (d) MS/MS spectrum of aconitine.

Aconitine was also found in the extract of the interior root piece $(27 \mu \mathrm{g} / \mathrm{g})$. In addition, jesaconitine $(\mathrm{m} / \mathrm{z}$ 676.33), hypaconitine $(\mathrm{m} / \mathrm{z}$ 616.31), and mesaconitine $(\mathrm{m} / \mathrm{z} 632.31)$ were identified. The relative amount of aconitine was $89 \%$, that of mesaconitine, hypaconitine, and jesaconitine $5 \%, 4 \%$, and $2 \%$, respectively. The minor occurring alkaloids were only detected in the root piece, not in the urine or in the femoral blood sample.

\subsection{Quantitation of Aconitine in Diverse Specimens}

As expected, aconitine was detected in all the other specimens taken during autopsy (Table 2). The highest concentration was found in gastric content $(55.2 \mu \mathrm{g} / \mathrm{mL})$, followed by bile fluid $(11.7 \mu \mathrm{g} / \mathrm{mL})$, liver $(9.14 \mu \mathrm{g} / \mathrm{g})$, urine $(1.74 \mu \mathrm{g} / \mathrm{mL})$, heart blood $(0.47 \mu \mathrm{g} / \mathrm{mL})$, and femoral blood $(0.15 \mu \mathrm{g} / \mathrm{mL})$. The least amount was found in cerebrospinal fluid $(0.07 \mu \mathrm{g} / \mathrm{mL})$. From these values, we conclude that aconitine was subject to postmortem redistribution, as the central blood/peripheral blood $(\mathrm{C} / \mathrm{P})$ ratio was 3 and the liver/peripheral blood $(\mathrm{L} / \mathrm{P})$ ratio $61 \mathrm{~L} / \mathrm{kg}$ [13].

\subsection{Postmortem Aconitine Metabolism}

According to literature, aconitine is metabolized by several P450 CYP enzymes [14]. Typical metabolites after aconitine consumption are $\mathrm{O}$-demethyl-aconitine, $\mathrm{N}$-deethyl-aconitine, $\mathrm{O}$-didemethyl-aconitine, 3-dehydrogen-aconitine, and hydroxyl-aconitine. In our case, we found $\mathrm{N}$-deethyl-aconitine $\left(m / z=618.29 ; \mathrm{C}_{32} \mathrm{H}_{44} \mathrm{NO}_{11}{ }^{+}, 0.4 \mathrm{ppm}\right)$ and 3-dehydrogen-aconitine $\left(m / z=644.31 ; \mathrm{C}_{34} \mathrm{H}_{46} \mathrm{NO}_{11}{ }^{+}\right.$, 
$-1 \mathrm{ppm})$ in the bile fluid and 3-dehydrogen-aconitine $\left(\mathrm{C}_{34} \mathrm{H}_{46} \mathrm{NO}_{11}{ }^{+}\right)$only in the urine sample. Tandem mass spectrometry (MS/MS) spectra of both compounds can be found in Figure 3.

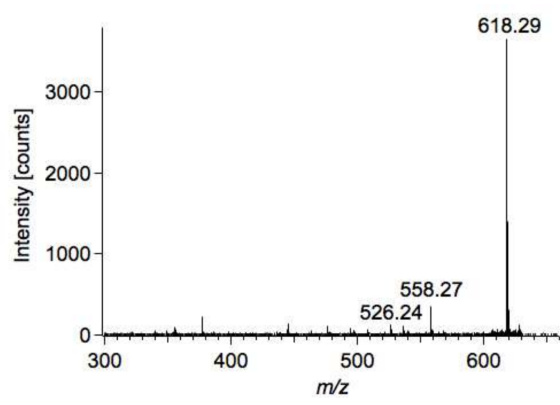

(a)

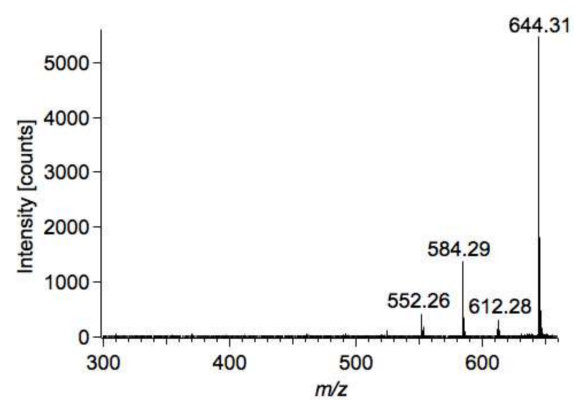

(b)

Figure 3. Tandem mass spectrometry (MS/MS) spectra of (a) $N$-deethyl-aconitine and (b) 3-dehydrogenaconitine.

\section{Discussion}

The medication (ibuprofen, diphenhydramine, trimethoprim) found in femoral blood was not overdosed. In order to find the toxin, the urine sample was profiled by LC-HRMS/MS. As aconitine is readily distributed in the human body, it is not routinely detected by common GC/MS-based systematic toxicological analysis.

Besides GC/SIM [15], LC-MS/MS is a valid and precise method for the analysis of the alkaloid content in blood and urine [4]. To explore unexplained deaths, it is worth considering LC-MS/MS for the profiling of specimens taken during autopsy.

Table 2. Concentration distribution of aconitine among various specimens taken during autopsy. n.d.: not determined. Hofman [17] only detected the alkaloid aconitine. Nitsu [16] found aconitine and mesaconitine in the specimens investigated. The values for mesaconitine are given in brackets. Maximum values are highlighted in red bold letters.

\begin{tabular}{cccc}
\hline Specimen & Our Values & Hofmann & Nitsu Case III \\
\hline cerebrospinal fluid & $0.07 \mu \mathrm{g} / \mathrm{mL}$ & $0.01 \mu \mathrm{g} / \mathrm{mL}$ & n.d. \\
femoral blood & $0.15 \mu \mathrm{g} / \mathrm{mL}$ & $0.02 \mu \mathrm{g} / \mathrm{mL}$ & $0.11 \mu \mathrm{g} / \mathrm{mL}(0.13 \mu \mathrm{g} / \mathrm{mL})$ \\
heart blood & $0.47 \mu \mathrm{g} / \mathrm{mL}$ & $0.05 \mu \mathrm{g} / \mathrm{mL}$ & $0.23 \mu \mathrm{g} / \mathrm{mL}(0.26 \mu \mathrm{g} / \mathrm{mL})$ \\
urine & $1.74 \mu \mathrm{g} / \mathrm{mL}$ & $0.28 \mu \mathrm{g} / \mathrm{mL}$ & $0.03 \mu \mathrm{g} / \mathrm{mL}(0.05 \mu \mathrm{g} / \mathrm{mL})$ \\
liver & $9.14 \mu \mathrm{g} / \mathrm{g}$ & $0.21 \mu \mathrm{g} / \mathrm{g}$ & $2.36 \mu \mathrm{g} / \mathrm{g}(2.14 \mu \mathrm{g} / \mathrm{g})$ \\
bile fluid & $11.7 \mu \mathrm{g} / \mathrm{mL}$ & n.d. & n.d. \\
gastric contents & $55.2 \mu \mathrm{g} / \mathrm{mL}$ & $0.01 \mu \mathrm{g} / \mathrm{mL}$ & n.d. \\
\hline
\end{tabular}

However, the qualitative and quantitative composition depends on plant species and ecological factors. Mizugaki et al. detected mesaconitine, aconitine, hypaconitine, and their hydrolysis products in serum [5]. Niitsu et al. presented three autopsy cases of suicide by aconite poisoning. They found jesaconitine in the first autopsy case, mesaconitine in the second autopsy case, and mesaconitine as well as aconitine in the third autopsy case [16].

In addition, a low margin of safety is assumed between the therapeutic and toxic doses. According to Moritz et al. [11], a 21-year-old man had taken one capsule Aconitum napellus a day to calm his anxiety. A few weeks later he decided to increase the effect by ingesting three capsules a day, with the result that he arrived in the emergency department; however, cardiovascular symptoms and neurological symptoms disappeared several hours after ingestion [11]. A similar phenomenon was observed in eight patients, who suffered from accidental intoxication after ingesting chuanwu and caowu. First symptoms began 0.5 to $1.5 \mathrm{~h}$ after drinking the herbal broth and lasted up to $30 \mathrm{~h}$. Most subjects experienced a combination of cardiovascular, gastrointestinal, and neurological symptoms [1]. In our study, aconitine 
reached relatively high concentrations in the gastric contents, bile fluid, and liver (Table 2). Nitsu et al. [16] also found the highest aconitine concentration in the liver and least concentration in femoral blood. This also holds true for Hofmann et al. [17]. Interestingly, the amount detected in gastric content was comparable to that in the cerebrospinal fluid.

Regardless of the mode of intake (eating aconite leaves and roots, drinking liquor in which roots were soaked), aconitum alkaloids were found predominantly in the liver, kidney, and bile [8]. In our autopsy case, the concentration of aconitine was high in all specimens taken during autopsy compared to other autopsy cases reported [16-19]. Thus, we conclude that an overdose of aconitine led to death.

\section{Conclusions}

The LC/HRMS-based screening approach contributed to the clarification of the case. However, from our experiments we cannot conclude whether the young man suffered from a derailed intoxication attempt or chose suicide. From literature it is known that aconitum is a very poisonous plant. Consequently, it might be expected that ingesting contents of a bottle filled with root pieces soaked in ethanol would end in death, in particular if one considers that ethanol increases the absorption of aconitine. Furthermore, aconitum plants possess a low therapeutic index. Thus, aconite extracts are surely known to present an unpredictable danger.

In case the GC/MS-based screening approach fails and clear evidence related to intoxication is found during autopsy and the investigative work, we recommend applying LC-HRMS/MS. This approach is not limited to the analysis of plant toxins. Any putative toxin occurring within the set mass range at a sufficient concentration will be detected.

Author Contributions: Conceptualization, N.T. and S.S.; methodology related to autopsy, M.W.; validation, E.V. and N.T.; formal analysis, E.V. and N.T.; investigation (autopsy finding), M.W.; investigation (toxicological analysis), E.V. and N.T.; writing—original draft preparation, N.T.; writing—review and editing, M.W., S.S., and M.T. All authors have read and agreed to the published version of the manuscript.

Funding: This research received no external funding.

Institutional Review Board Statement: The study was conducted according to the guidelines of the Declaration of Helsinki.

Informed Consent Statement: Informed consent was obtained from all subjects involved in the study.

Data Availability Statement: The data presented in this study are all provided in the main text. There does not exist any additional supplementary material.

Conflicts of Interest: The authors declare no conflict of interest.

\section{References}

1. Chan, T.Y.; Tomlinson, B.; Critchley, J.A. Aconitine poisoning following the ingestion of Chinese herbal medicines: A report of eight cases. Aust. N. Z. J. Med. 1993, 23, 268-271. [PubMed]

2. Li, H.; Liu, L.; Zhu, S.H.; Liua, Q. Case reports of aconite poisoning in mainland China from 2004-2015: A retrospective analysis. J. Forensic Leg. Med. 2016, 42, 68-73. [CrossRef] [PubMed]

3. Singhubera, J.; Zhua, M.; Prinza, S.; Koppa, B. Aconitum in Traditional Chinese Medicine-A valuable drug or an unpredictable risk? J. Ethnopharmacol. 2009, 126, 18-30. [CrossRef] [PubMed]

4. Gao, X.; Hu, J.; Zhang, X.; Zuo, Y.; Wang, Y.; Zhu, S. Research progress of aconitine toxicity and forensic analysis of aconitine poisoning. Forensic Sci. Res. 2020, 5, 25-31. [CrossRef] [PubMed]

5. Mizugaki, M.; Ito, K.; Ohyama, Y.; Konishi, Y.; Tanaka, S.; Kurasawa, K. Quantitative analysis of Aconitum alkaloids in the urine and serum of a male attempting suicide by oral intake of aconite extract. J. Anal. Toxicol. 1998, 22, 336-340. [CrossRef] [PubMed]

6. Kaneko, R.; Hattori, S.; Furuta, S.; Hamajima, M.; Hirata, Y.; Watanabe, K.; Seno, H.; Ishii, A. Sensitive analysis of aconitine, hypaconitine, mesaconitine, and jesaconitine in human body fluids and Aconitum tubers by LC/ESI-TOF-MS. J. Mass Spectrom. 2006, 41, 810-814. [CrossRef] [PubMed] 
7. Beike, J.; Frommherz, L.; Wood, M.; Brinkmann, B.; Köhler, H. Determination of aconitine in body fluids by LC-MS-MS. Int. J. Legal Med. 2004, 118, 289-293. [PubMed]

8. Baselt, R.C. Disposition of Toxic Drugs and Chemicals in Man, 12th ed.; Biomedical Publications: Seal Beach, CA, USA, June 2020; pp. 32-33.

9. Gutser, U.T.; Friese, J.; Heubach, J.F.; Matthiesen, T.; Selve, N.; Wilffert, B.; Gleitz, J. Mode of antinociceptive and toxic action of alkaloids of Aconitum spec. Naunyn-Schmiedeberg's Arch. Pharmacol. 1998, 357, $39-48$. [CrossRef] [PubMed]

10. Tai, Y.T.; But, P.P.; Young, K.; Lau, C.P. Cardiotoxicity after accidental herb-induced aconite poisoning. Lancet 1992, 340, 1254-1256. [CrossRef]

11. Moritz, F.; Compagnon, P.; Kaliszczak, I.G.; Kaliszczak, Y.; Caliskan, V.; Girault, C. Severe acute poisoning with homemade Aconitum napellus capsules: Toxicokinetic and clinical data. Clin. Toxicol. 2005, 43, 873-876. [CrossRef] [PubMed]

12. Tan, G.; Lou, Z.; Jing, J.; Li, W.; Zhu, Z.; Zhao, L.; Zhang, G.; Chai, Y. Screening and analysis of aconitum alkaloids and their metabolites in rat urine. Biomed. Chromatogr. 2011, 25, 1343-1351. [CrossRef] [PubMed]

13. McIntyre, I.M. Liver and peripheral blood concentration ratio (L/P) as a marker of postmortem drug redistribution: A literature review. Forensic Sci. Med. Pathol. 2014, 10, 91-96. [PubMed]

14. Tang, L.; Ye, L.; Lv, C.; Zheng, Z.; Gong, Y.; Liu, Z. Involvement of CYP3A4/5 and CYP2D6 in the metabolism of aconitine using human liver microsomes and recombinant CYP450 enzymes. Toxicol. Lett. 2011, 202, 47-54. [PubMed]

15. Yoshioka, N.; Gonmori, K.; Tagashira, A.; Boonhooi, O.; Hayashi, M.; Saito, Y.; Mizugaki, M. A case of aconitine poisoning with analysis of aconitine alkaloids by GC/SIM. Forensic Sci. Int. 1996, 81, 117-123. [PubMed]

16. Niitsu, H.; Fujita, Y.; Fujita, S.; Kumagai, R.; Takamiya, M.; Aoki, Y.; Dewa, K. Distribution of Aconitum alkaloids in autopsy cases of aconite poisoning. Forensic Sci. Int. 2013, 227, 111-117. [PubMed]

17. Hofmann, V.; Landmann, A.; Schmitt, G.; Krauskopf, A.; Bartel, M. A fatal case of aconite poisoning: Accidental intake of a monkshood extract. Forensic Toxicol. 2020, 38, 511-516.

18. Elliott, S.P. A case of fatal poisoning with the aconite plant: Quantitative analysis in biological fluid. Sci. Justice 2002, 42, 111-115. [CrossRef]

19. Pullela, R.; Young, L.; Gallagher, B.; Avis, S.P.; Randell, E.W. A case of fatal aconitine poisoning by Monkshood ingestion. J. Forensic Sci. 2008, 53, 491-494. [CrossRef] [PubMed]

Publisher's Note: MDPI stays neutral with regard to jurisdictional claims in published maps and institutional affiliations.

(C) 2021 by the authors. Licensee MDPI, Basel, Switzerland. This article is an open access article distributed under the terms and conditions of the Creative Commons Attribution (CC BY) license (http://creativecommons.org/licenses/by/4.0/). 